\title{
Peatland Fires in Riau, Indonesia, in Relation to Land Cover Type, Land Management, Landholder, and Spatial Management
}

\author{
Prayoto $^{1 *}$, Masae Iwamoto Ishihara1,2, Rachmad Firdaus ${ }^{3}$, Nobukazu Nakagoshi ${ }^{1}$ \\ ${ }^{1}$ Graduate School for International Development and Cooperation, Hiroshima University, Higashi-Hiroshima, Japan \\ ${ }^{2}$ Field Science Education and Research Center, Kyoto University, Kyoto, Japan \\ ${ }^{3}$ Division of Forestry Governance, Coordinating Ministry for Economic Affairs, Jakarta, Indonesia \\ Email: *mrpray2000@gmail.com
}

How to cite this paper: Prayoto, Ishihara, M.I., Firdaus, R. and Nakagoshi, N. (2017) Peatland Fires in Riau, Indonesia, in Relation to Land Cover Type, Land Management, Landholder, and Spatial Management. Journal of Environmental Protection, 8, 1312-1332. https://doi.org/10.4236/jep.2017.811081

Received: September 29, 2017

Accepted: October 27, 2017

Published: October 30, 2017

Copyright $\odot 2017$ by authors and Scientific Research Publishing Inc. This work is licensed under the Creative Commons Attribution International License (CC BY 4.0).

http://creativecommons.org/licenses/by/4.0/

\begin{abstract}
Peatland in Southeast Asia has an important function in the provision of ecosystem services such as carbon sink, climate regulation, water supply, biodiversity, and others. Recurrent fires in the peatland, especially in Indonesia, have changed peatland functions from carbon sequestration to carbon emission, causing severe environmental and economic problems. Fire prevention requires an understanding of the factors affecting fire in peatland. We compared fire occurrences in 2014 between different land cover types, land management systems, landholders, and proximity to roads and canals in Riau Province, Indonesia. Remote sensing and field data were collected and analyzed. Shrubland was the most fire-prone land cover, while plantations and mangrove forests were the least. Shrubland has high fire occurrence regardless of land management and landholder type. Peat swamp forests that are allowed to be utilized were more fire-prone than conserved peat swamp forests. Oil palms from unregistered companies had more fires than those from registered companies and smallholders. Coconut and sago plantations from companies had more fires than smallholder cultivation. Proximity to roads and canals affects the occurrence of fires in peat swamp forests; however, proximity had less of an effect on fire occurrence in shrubland. The high percentage of burned areas in shrubland showed that land cover was a major factor that affects fire in peatland, followed by land management, landholders, and proximity to roads and canals. These findings indicate the importance of law enforcement and land management systems, management schemes by different landholders, and the spatial arrangement of land cover, roads, and canals for integrated peatland management and restoration of shrubland into peat swamp forest and other fire-resistant land cover types with sustainable production.
\end{abstract}




\section{Keywords}

Peatland, Landscape, Fire Regime, Fire Dynamic, Plantation, Proximity

\section{Introduction}

Peatland is a wetland ecosystem in which the production of organic matter from dead plants is higher than its decomposition. Several factors influence peatland formation, including climate, humidity, topography, and geology [1]. The majority of peatlands are located in temperate and boreal zones under low-temperature conditions. However, regional environmental and topographic conditions have resulted in the formation of tropical peat swamp forests in Southeast Asia, Southern Africa, South America, and Central America.

Peatlands provide various ecosystem services. Peatlands store 500 - $700 \mathrm{G}$ ton of carbon, yet it only covers 3\% of the Earth's surface [2]. The majority of this carbon is stored in temperate and boreal peatlands, but tropical peat swamp forests also store a significant amount of carbon at around 80 - $90 \mathrm{G}$ ton, $69 \mathrm{G}$ ton of which is stored in Southeast Asia. Furthermore, peat swamp forests in Southeast Asia provide other ecosystem services such as climate regulation, water supply, and supporting high biodiversity [3].

When tropical peatland starts to burn, it will release a significant amount of carbon into the atmosphere (243 ton per hectare [4]). Peatland fires have changed peatland function in Southeast Asia from carbon sink to a carbon source [5]. Moreover, in recent years, persistent peatland fires have been identified as a hazard with serious effects on human society. The total economic, social, and ecological damages and losses due to fires in Indonesia were estimated to be at least 16.1 billion USD in 2015 [6]. The effect of fires on peatland ecosystems may persist for a long time [7].

Peatland fires have a long history, and they are not a new phenomenon in Southeast Asia. Major fire events occurred in Kalimantan in 1846, 1902, 1915, and 1972, all of which were El Niño Southern Oscillation (ENSO) years [8]. El Niño reduced precipitation drastically [9], which makes peatland more susceptible to fire due to lowered water table [10]. Local communities in East Kalimantan and South Sumatra have traditionally conducted slashing and burning in peat swamp forests along the river bank and forest edges to convert the forest to agricultural land ([11] [12]).

However, fire has become a more frequent and severe problem in Southeast Asia since the late 1990s [13]. Visibility records from the airports in Sumatra and Kalimantan since the 1960s indicate higher fire frequency after industrial plantations or the Mega Rice Project in Kalimantan began [14]. Twenty percent of peat swamp forests in Malaysia Peninsular, Sumatra, and Kalimantan were transformed to industrial plantations by 2010 [15]. Fire was a tool for land preparation after logging to create plantations by palm oil and industrial forest companies [16]. 
Furthermore, the water table was lowered by the creation of canals to grow oil palms or acacia plantations and to create large-scale rice paddy fields, which increased fire risk [17]. Industrial plantation concessions contributed to fire ten times higher than selective logging concessions ([18]).

Fires may be prevented by sustainable management practices [19]. Fire occurrences in Southeast Asian peatland depend on land cover [20]. Many studies have reported that fires occurred more frequently in deforested areas than in forests or oil palm and acacia plantations, fires originated and spread from deforested areas more often than oil palm plantations and settlements in Central Kalimantan [21]. The sources of fires have shifted from peat swamp forests due to slash and burn to deforested areas since 2002 due to the Mega Rice Project [22]. In Riau, most of the burned area was a deforested area expanded by a previous fire or created due to the failure of industrial plantation development [23]. To prevent recurrent peatland fires, factors that affect fire occurrences besides climate should be elucidated.

Despite deforested areas consisting of various land cover types, such as shrubland regenerated after a fire [24], rice paddy fields, coconut and rubber cultivation, young oil palm plantations, and bare soil, most of previous studies have not classified these land cover types as they used moderate-resolution satellite images to cover large regions. These deforested land covers may contribute to fire occurrence differently. In Jambi Province, Stolle et al. [25] demonstrated that few fires occurred in rice paddy fields, coconut, plantations, grassland, and rubber cultivation. In contrast, recurrent fires occurred in shrubland, and ferns dominated vegetation that grew after fire [26]. Young oil palm and acacia plantations in South Sumatra were susceptible to fires [27]. Understanding which types of deforested land cover are more prone to fire is necessary for sustainable development of peatland.

Although all land belongs to the Indonesian government, land is used by different landholders. Concession holders may not control all the land within their management area as migrants and local communities may claim land tenure in the concession area and forests [28]. Land discrepancies among existing conditions, concession holders, and land management are major problem in peatland management. Owing to land discrepancies, the government has difficulties in identifying the responsible parties for peatland fire [29].

Even if the land cover type are the same, land management may influence fire occurrence. In Kalimantan, fewer fires occurred in protected forest areas than in forests allowed to selective logging or conversion to a plantation [30].

Fire occurrence may be also affected by landholder type. Land utilized by smallholders has generally been managed intensively and more protected against fires than concession areas [31], because smallholders cleared their land at smaller scale than concession companies. Oil palms are planted by either a registered large-scale concession company, an unregistered company, or smallholders in Indonesia [32]. The registered companies implemented a zero-burning policy to obtain a sustain- 
able management certification. This certificate is mandatory for all palm oil companies in Indonesia. In contrast, unregistered companies do not follow the policy and a company has used fire to develop plantations in an Indonesian national park [33].

The proximity to a road or canal could be another important factor affecting fire occurrence. Road intensity affects spatial fire distribution [34]. In Jambi, forests within $1-5 \mathrm{~km}$ of the road suffered fires almost five times more than forests over $20 \mathrm{~km}$ away from the road [25]. Similarly, in Kalimantan, most forest fires occurred within $5 \mathrm{~km}$ from the forest edge [30], and many fires occurred near canals [22]. Roads and canals are the main methods of access to plantations. Additionally, canal may also lower the level of the water table by drainage, thus creating a fire-prone environment.

This study aims to analyze relationship between fire occurrence and land cover type, land management, landholders, and proximity to roads and canals. We focus on Riau Province in Sumatra Island, Indonesia, because Riau has extensive peatlands, frequent fires, and has experienced rapid deforestation. The year we selected was 2014 due to severe impacts of fire (Figure 1) on the economy, social, and ecological aspects in Riau, where damage and loss totals an estimated 935 million USD [35]. We focus on four questions:

1) Are fire occurrences more frequent in shrubland than other land cover types?

2) Do fires occur more frequently in peat swamp forests allowed to convert to a plantation or other uses than protected peat swamp forests?

3) Is smallholder cultivation better for fire prevention than registered and unregistered companies?

4) Does closer proximity to road and canal result in more frequent fires?

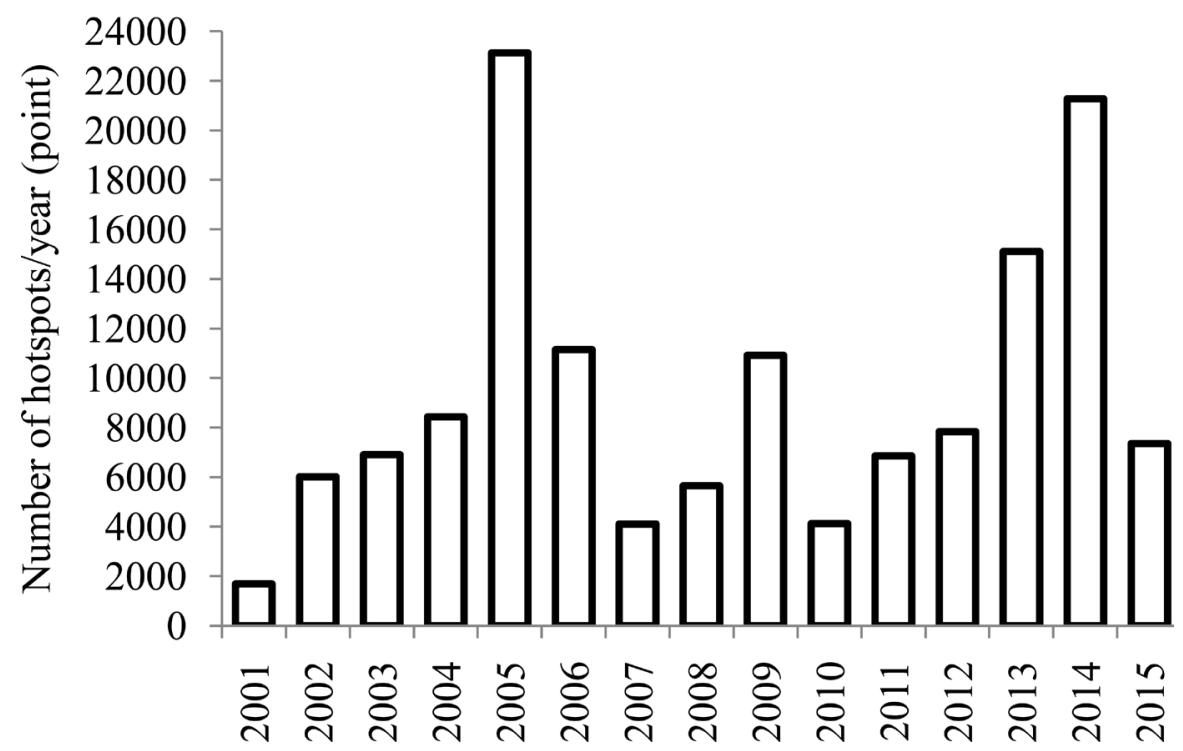

Figure 1. Number of MODIS fire hotspots from 2001 to 2015 on peatland. Source: http://firms.modaps.eosdis.nasa.gov/download/request.php. 


\section{Materials and Methods}

\subsection{Study Area}

Riau Province is located on the eastern coast of Sumatra island, stretching from the Barisan Hills downwards to Malacca Strait $\left(2^{\circ} 35^{\prime} \mathrm{N}-0^{\circ} 58^{\prime} \mathrm{S}, 100^{\circ} 13^{\prime} \mathrm{E}-103^{\circ} 50^{\prime} \mathrm{E}\right)$. Riau has a tropical climate, with annual mean precipitation and temperature of $2400 \mathrm{~mm}$ and $26^{\circ} \mathrm{C}$, respectively, between 2012 and 2014 [36].

\subsection{Mapping Riau's Peatland Post-Fire Land Cover Map in 2014}

A map of land cover after a severe fire between January and March 2014 was created using post-fire Landsat 8 images, acquired from April to November 2014. Landsat 8 has a spatial resolution of $15 \times 15 \mathrm{~m}$ [37]. The images from the period with less than 50\% cloud cover were used [38]. Satellite images were downloaded from the US Geological Survey National Center for Earth Resources Observation and Science via the Global Visualization Viewer (GLOVIS) data portal (http://glovis.usgs.gov/). This study was conducted with Landsat 8 pre-processing (atmospheric correction), land cover classification, and an accuracy check of land cover classification [39].

Atmospheric correction was conducted to reduce atmospheric distortion. To enhance image information Quantum GIS 2.14.2 Essen was used by transforming radiance at the sensor into surface reflectance values [40]. Physics-based derivation of surface and atmospheric properties of hyperspectral and multispectral data was presented by image enhancement process. This is based on atmospheric radioactive transfer, input of atmospheric parameters, and calibration of the instrument accuracy. Spectral differences were enhanced with the algorithm that divided spectral band (numerator) by another band (denominator) [37].

A supervised classification through maximum likelihood algorithm method in ArcGIS 10.2 software to classify land cover into 11 types (Table 1) was used. Training areas were used to define the spectral reflectance patterns of each land cover type in supervised classification. Classifier would use the pattern of training area to group the pixels of certain category with the same spectral patterns [41]. Pixel of an unknown category has a certain probability of belonging to a particular category in the maximum likelihood algorithm classifier. All categories had equal probabilities follows the Gaussian (normal) distribution function.

For the training areas, ground truth data were used. Geographical coordinates and land cover types were recorded in the field for 1301 sampling points during 2013-2015. To avoid pseudoreplication, stratified random sampling was conducted by the Sampling Design Tool [42] in ArcGIS 10.2. Ten percent of sampling points that were at least $5 \mathrm{~km}$ apart from each other were randomly sampled for each land cover type. The sampling points were not sufficient for some land cover types (shrubland, settlement, mangrove, and water body), so points were added using Google Earth images acquired from 2013 to 2015.

A training area was created for each sampling point with the assistance of vis- 
ual inspection of Landsat images through displaying RGB combination (bands 654) and the image from Google Earth. The training area was checked by the 2013 land cover map (the Ministry of Forestry and Prayoto unpublished data).

Accuracy assessment is an important step due to the land cover maps that derived from remote sensing commonly contain various errors as a result of method of satellite data capturing or the classification procedure [43]. The accuracy assessment usually used error matrix that represents the number of sample units (i.e., pixels, clusters of pixels, or polygons) in a set of numbers of rows and columns assigned to a particular type, relative to the actual type in verification data. For verification data, stratified random sampling was conducted for the remaining ground truth data that was not used for creating the training area. The Sampling Design Tool [42] was used to sample $50 \%$ of the points that were more than $5 \mathrm{~km}$ apart from each other for each land cover type. Google Earth was used to add additional data for the categories with few sampling points. User's accuracy was calculated by dividing the number of correctly identified ground truth points by the total number of verification points.

\subsection{Identification of Pre-Fire Land Cover}

To elucidate relationship between fire occurrence and land cover type, pre-fire land cover was identified for areas burned by the fire from January to March 2014. The burned area in the post-fire land cover map can be classified into two types: 1) areas burned by the fire in January to March 2014; and 2) areas burned before January 2014 or after March 2014. The former burned area was identified by the presence of Moderate Resolution Imaging Spectroradiometer (MODIS) fire hotspots during January $29^{\text {th }}$ to March $28^{\text {th }}$. Hotspot data were downloaded from the National Aeronautics and Space Administration via Fire Information for Resource Management System (FIRMS) data portal (http://firms.modaps.eosdis.nasa.gov/download/request.php/). MODIS fire hotspot data shows the coordinates of the center of $1 \times 1 \mathrm{~km}$ pixel where persistent fire was detected from a MODIS image using an algorithm ([21] [44]). For the areas burned by the fire in January to March 2014, the pre-fire land cover was determined through visual interpretation of Landsat 8 images acquired from September to December 2013, with Google Earth data as supportive data.

\subsection{Identification of Land Management System}

According to Indonesian forestry laws, peatland in Riau was divided into conservation forest, protection forest, production forest (limited production forest, regular production forest, and convertible production forest), and non-forestland. Conservation forest was assigned for maintaining biodiversity and ecosystems, and can be utilized for research purposes. Protection forest was assigned for protecting water systems, preventing flooding, soil erosion, seawater intrusion, and maintaining soil fertility, and can only be utilized for research purposes and non-timber forest products. Limited production forest was assigned for selective logging. Reg- 
ular production forest was assigned for producing wood through the clear-cutting system, planting, and harvesting industrial forests. Convertible production forest was assigned for wood production or conversion to non-forestland. Non-forestland was assigned for non-forestry activities, such as agriculture [38]. A land management map for 2011 was obtained from the Ministry of Forestry.

\subsection{Landholders}

Based on land management, the government has granted forestry concession and non-forestry concession. Industrial forest plantation concessions were granted for logging and acacia plantations in regular and limited production forests. Non-forestry concessions (cultivation right and forest release area) were granted for oil palm plantations in Riau on convertible production forest and non-forestland.

We categorized landholders into registered companies, unregistered companies, smallholders, cooperation between a company and smallholders, and unidentified landowners [23]. We identified the landholder of the area that was burned by fire in January to March 2014 using pre-fire land cover information, concession boundary data in 2013 that were issued by Ministry of Forestry and National Land Agency, and images from Landsat and Google Earth that were captured in 2013. Registered and unregistered company plantations exhibit more orderly clusters, with regular canals, roads, and palm oil mills. If the regular pattern was located inside the concession and covered by acacia, oil palm, coconut, or sago palm, it was categorized as a registered company. If the regular pattern of oil palms was located outside the concession, it was categorized as an unregistered company. Smallholder plantations were categorized by land parcels of irregular shape, varying size and direction, and covered by oil palm, coconut, and sago palms. The boundaries of those grids were constructed by visual interpretation. These patterns are visible on the Landsat 8 and Google Earth images. Usually, acacia plantations were developed inside the concession area; however, occasionally the companies cooperate with the local community to plant acacia outside their concession area [45]. If an acacia plantation was found outside the concession, these were categorized as cooperation between a company and smallholders. For shrubland, we could not identify landholders by our method as migrants may encroach the shrubland under concession.

\subsection{Map Analysis and Proximity Analysis}

To elucidate relationship between fire occurrence and land cover type, land management, landholders, and accessibility, geospatial analysis was conducted using ArcGIS 10.2. The burned area map was overlaid onto the land cover map, land management map, and the map of landholder. We conducted buffer analysis for the roads and canals to test whether proximity affects fire occurrence. The probability of a burned area was compared between areas with different proximity to roads and canals. A buffer area was created every $1 \mathrm{~km}$ up to $5 \mathrm{~km}$ for the canal and every $1 \mathrm{~km}$ up to $10 \mathrm{~km}$ for the road. 


\subsection{Statistical Analysis}

Data of forest patch sizes were analyzed with R statistical software. Analysis of variance (ANOVA) was used to determine significant differences between forest group at confidence level of $\mathrm{p}<0.05$.

\section{Results and Discussion}

\subsection{Accuracy Assessment for Land Cover Classification}

The user's accuracy of each land cover was $65 \%-100 \%$ (Table 1) and the producer's accuracy was $75 \%-100 \%$. The overall accuracy and the Kappa coefficient was $83 \%$ and 0.81 , respectively. It indicated that image classification was good [46].

\subsection{Land Cover Types and Land Management}

Plantations and agricultural land covered $47 \%$ of peatland (Table 2; Figure 2). Oil palm plantations were the most dominant type (17\%), followed by coconut (13.9\%), and acacia (13.5\%). Peat swamp forests covered only $29.2 \%$ of peatland.

Peatlands in Riau were categorized into conservation forest (Table 3; 5.7\%), protected forest $(0.3 \%)$, production forest $(77.5 \%)$, and non-forestland (16.5\%). Half of the peatland has been granted concessions, namely cultivation rights (10.2\% of peatland), industrial forest plantation (30.4\%), and release of forest area $(8.5 \%)$.

Peatland utilization is expected to be determined by the type of land management and concessions. However, there was a discrepancy between actual peatland utilization and the types of land management and concessions. For instance,

Table 1. Accuracy assessment for land cover classification.

\begin{tabular}{|c|c|c|c|c|c|c|c|c|c|c|c|c|c|}
\hline \multirow{2}{*}{ Land cover classification } & \multicolumn{11}{|c|}{ Reference data } & \multirow{2}{*}{ Total } & \multirow{2}{*}{$\begin{array}{c}\text { User's } \\
\text { accuracy (\%) }\end{array}$} \\
\hline & Ac & $\mathrm{Ba}$ & $\mathrm{Cc}$ & $\mathrm{Mg}$ & Op & Ps & $\mathrm{Rb}$ & Sp & St & $\mathrm{Sh}$ & $\mathrm{Wb}$ & & \\
\hline Acacia (Ac) & 17 & 2 & 0 & 0 & 2 & 2 & 0 & 0 & 0 & 1 & 0 & 24 & 71 \\
\hline Burned area $(\mathrm{Ba})$ & 4 & 43 & 1 & 0 & 6 & 3 & 2 & 1 & 0 & 6 & 0 & 66 & 65 \\
\hline Coconut $(\mathrm{Cc})$ & 0 & 0 & 18 & 1 & 1 & 0 & 0 & 1 & 0 & 0 & 0 & 20 & 90 \\
\hline Mangrove (Mg) & 0 & 0 & 0 & 24 & 0 & 0 & 0 & 1 & 2 & 0 & 0 & 27 & 89 \\
\hline Oil palm (Op) & 1 & 2 & 0 & 2 & 43 & 0 & 0 & 0 & 1 & 4 & 0 & 53 & 81 \\
\hline Peat swamp forest (Ps) & 1 & 0 & 0 & 0 & 1 & 24 & 0 & 1 & 0 & 0 & 0 & 27 & 89 \\
\hline Rubber (Rb) & 0 & 0 & 0 & 0 & 0 & 0 & 18 & 0 & 0 & 0 & 0 & 18 & 100 \\
\hline Sago palm (Sp) & 0 & 0 & 0 & 0 & 0 & 0 & 0 & 33 & 0 & 1 & 0 & 34 & 97 \\
\hline Settlement (St) & 0 & 0 & 0 & 0 & 0 & 0 & 0 & 0 & 22 & 0 & 0 & 22 & 100 \\
\hline Shrub land (Sh) & 0 & 0 & 0 & 0 & 0 & 3 & 0 & 0 & 1 & 33 & 0 & 40 & 83 \\
\hline Water body (Wb) & 0 & 0 & 1 & 0 & 0 & 1 & 0 & 0 & 2 & 0 & 24 & 28 & 86 \\
\hline Total & 23 & 47 & 20 & 27 & 55 & 33 & 20 & 37 & 28 & 45 & 24 & 359 & Overall accuracy \\
\hline Producer's accuracy (\%) & 74 & 91 & 90 & 89 & 78 & 73 & 90 & 89 & 79 & 73 & 100 & & $83.3 \%$ \\
\hline
\end{tabular}


Table 2. Area burned by fire between January and March 2014, and post-fire.

\begin{tabular}{cccccc}
\hline Land cover & $\begin{array}{c}\text { (A) Area } \\
\text { after the fire } \\
\text { (ha) }\end{array}$ & $\begin{array}{c}\text { Proportion of } \\
\text { A to the total } \\
\text { area (\%) }\end{array}$ & $\begin{array}{c}\text { (B) Burned } \\
\text { area (ha) }\end{array}$ & $\begin{array}{c}\text { Proportion of B } \\
\text { to the total } \\
\text { burned area (\%) }\end{array}$ & $\begin{array}{c}\text { (B/(B + A)) } \\
\text { Percentage of } \\
\text { burned area (\%) }\end{array}$ \\
\hline Shrubland & 378,110 & 9.4 & 157,794 & 36.8 & 29.4 \\
Sago palm & 61,653 & 1.5 & 14,735 & 3.4 & 19.3 \\
Burned area & 463,925 & 11.5 & 43,099 & 10.0 & 9.3 \\
Peat swamp forest & $1,177,034$ & 29.2 & 118,923 & 27.7 & 9.2 \\
Acacia & 544,740 & 13.5 & 39,633 & 9.2 & 6.8 \\
Water body & 14,210 & 0.4 & 906 & 0.2 & 6.0 \\
Oil palm & 686,280 & 17.0 & 29,554 & 6.9 & 4.1 \\
Coconut & 560,413 & 13.9 & 21,463 & 5.0 & 3.7 \\
Rubber & 61,215 & 1.5 & 1884 & 0.4 & 3.0 \\
Mangrove & 66,759 & 1.7 & 1134 & 0.3 & 1.7 \\
Settlement & 14,952 & 0.4 & 31 & 0.0 & 0.2 \\
Total & $4,029,292$ & 100 & 429,155 & 100 & 10.7 \\
\hline
\end{tabular}

Table 3. Fire occurrence in 2014 in different concession and land management.

\begin{tabular}{ccccc}
\hline & (A) Area (ha) $\begin{array}{c}\text { Proportion of A } \\
\text { to the total area (\%) }\end{array}$ & $\begin{array}{c}\text { (B) Burned } \\
\text { area (ha) }\end{array}$ & $\begin{array}{c}\text { (B/(A) Percentage } \\
\text { of burned area (\%) }\end{array}$ \\
\hline Concession types & & & & \\
Cultivation right & 411,285 & 10.2 & 47,351 & 11.5 \\
Release of forest area & $1,225,027$ & 30.4 & 136,037 & 11.1 \\
Industrial forest plantation & $2,051,048$ & 8.5 & 42,349 & 9.9 \\
Outside concession & 341,932 & 50.9 & 203,419 & 12.4 \\
Total & $4,029,292$ & & 429,155 & \\
Land management types & & & & 12.2 \\
Non-forestland & 666,046 & 16.5 & 81,213 & 2.5 \\
Convertible production forest & 10,964 & 0.3 & 279 & 8.2 \\
Limited production forest & $1,362,289$ & 33.8 & 111,539 & 9.6 \\
Protection forest & $1,132,257$ & 28.1 & 108,332 & 19.1 \\
Regular production forest & 629,537 & 15.6 & 120,313 & 3.3 \\
Conservation forest & 228,043 & 5.7 & 7480 & \\
Total & $4,029,292$ & & 429,155 & \\
\hline
\end{tabular}

Source: Geospatial analyst of land cover map 2014 and boundary of concession and land management.

we detected $5.2 \%$ of oil palm plantations inside industrial forest plantation concessions where acacia should be planted (Figure 3), 8.2\% of oil palm plantations inside regular production forest where only acacia was permitted to be planted (Figure 4), and $11.8 \%$ of oil palm plantations inside limited production forest where selective logging was permitted (Figure 5). 


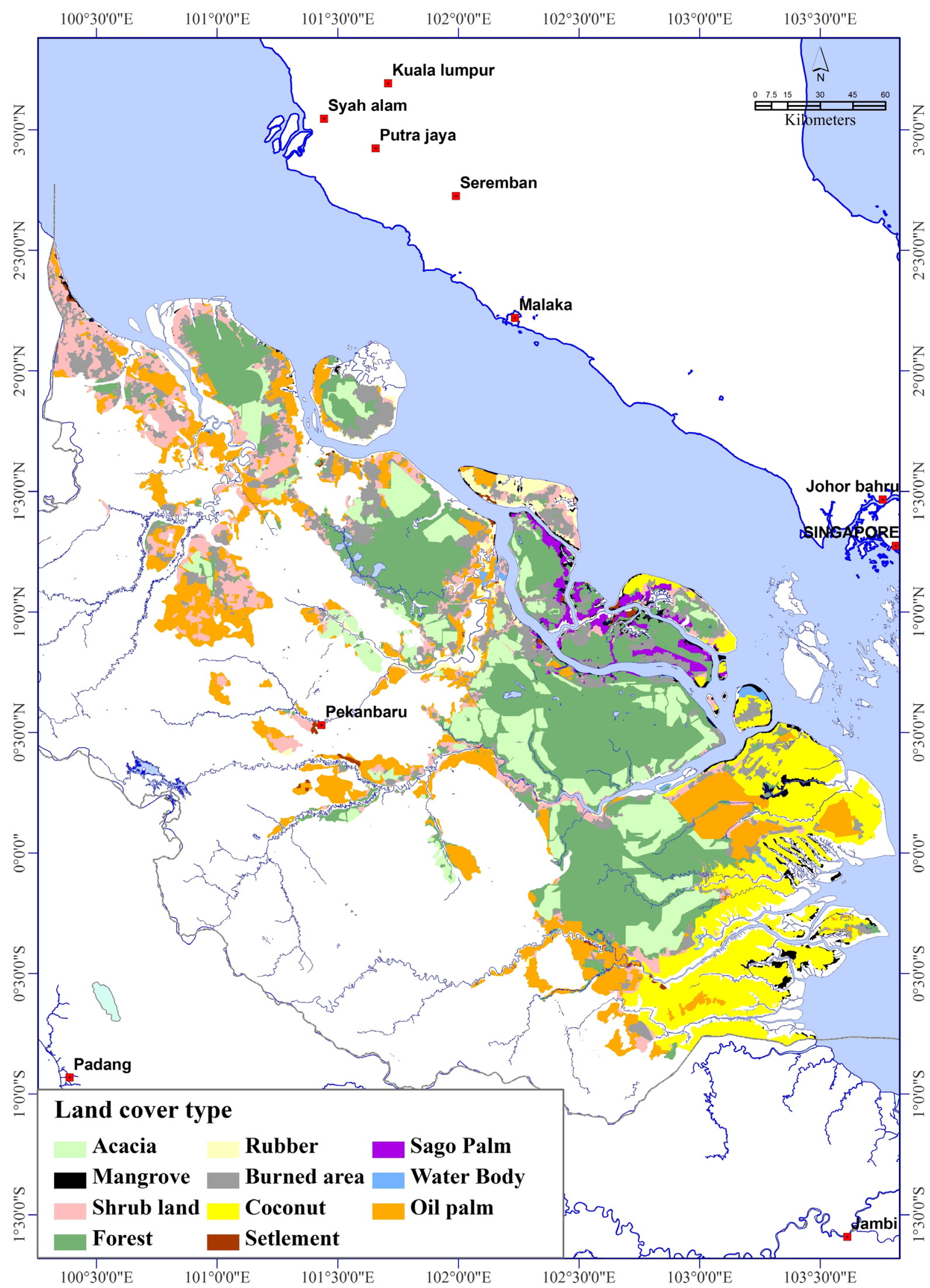

Figure 2. Land cover map 2014 of peatland in Riau, Indonesia. 


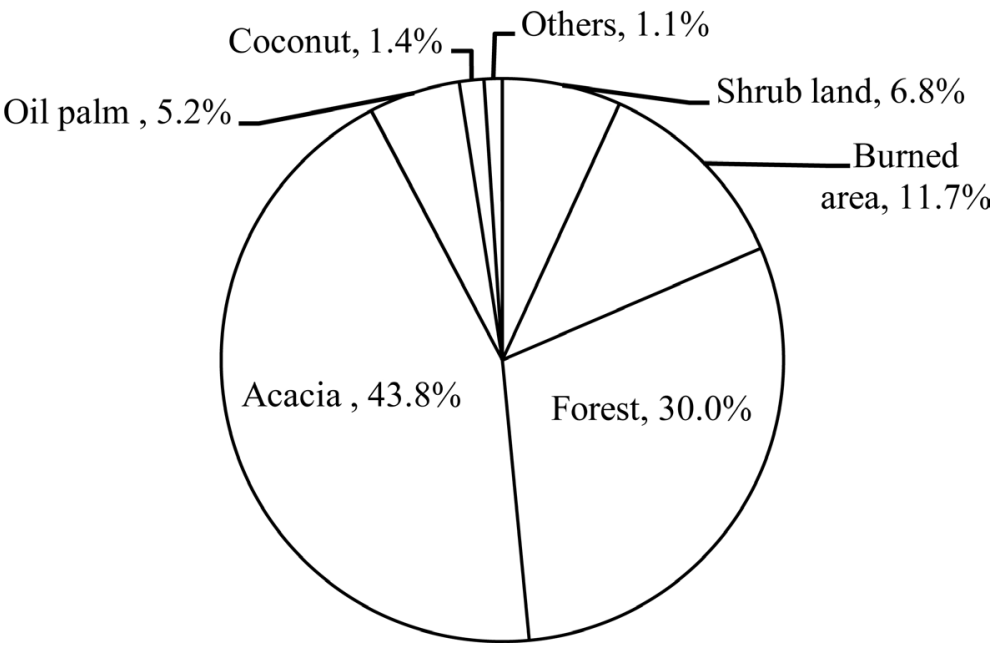

Figure 3. Percentage of land cover map in industrial forest concession.

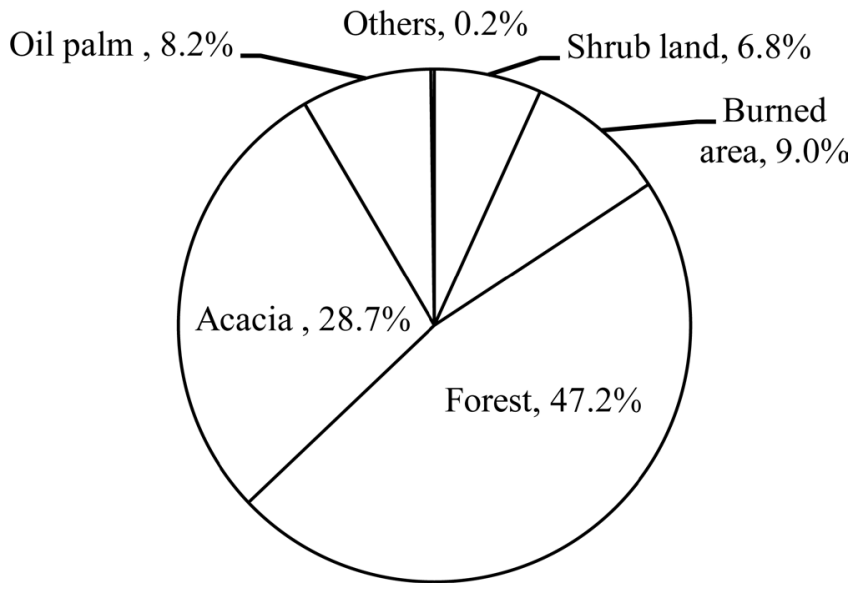

Figure 4. Percentage of land cover map in regular production forest.

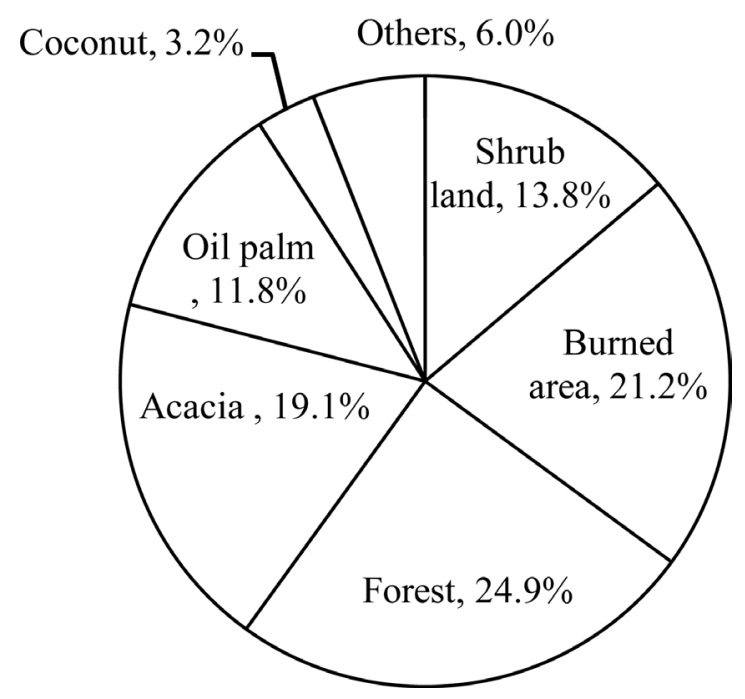

Figure 5. Percentage of land cover map in limited production forest. 


\subsection{Land Cover Types and Fire Occurrences}

Eleven percent of peatland was burned by the fires between January and March 2014 (Table 2). Most of the burned areas were shrublands (36.8\%) and peat swamp forests (27.7\%). Conversely, burning was lower in plantation areas, with $9.2 \%$ of fires occurring in acacia plantations, $6.9 \%$ in oil palms and $5 \%$ in coconut plantations. Different land cover types faced different occurrences of fire. The more fire-prone land cover types were shrublands, where $29.4 \%$ of it burned, followed by sago palm plantations (19.3\%), areas that were burned in 2013 (9.3\%), and peat swamp forests $(9.2 \%)$. Rubber and mangroves were the least fire-prone land cover types.

More than one-third of burned areas were located in shrubland, which was the most fire prone land cover type (Table 2), as we predicted. This result supports previous studies which found that deforested and unmanaged areas were the main source of fire ([23] [47]). Shrubland is dominated by fire-prone ferns and grass species [48], and contains recovering vegetation that appears after fires or when oil palm plantations are not well managed [49]. Migrants and local communities use fire for clearing land in shrubland to develop oil palm plantation [50]. The combination of fire-prone vegetation and social factors make shrubland the most burned land cover type.

Peat swamp forests were less susceptible to fire than shrubland (Table 2). Intact peat swamp forests are resistant to fire because the ecosystem is moist throughout the year [2]. Soil moisture in peat swamp forests is high because of the tree canopy, while in shrubland, sunlight directly reaches the ground's surface [51]. In our results, $9 \%$ of peat swamp forests were burned, while $6 \%$ and $0.1 \%$ of intact peat swamp forests were burned in Kalimantan in 2002 and 2005, respectively [52], and 3.8\% of logged-over forests and $0.7 \%$ of intact forests were burned in Jambi in 1993 [25]. The differences between our results and those of previous studies could be because we did not differentiate between intact, secondary, and degraded forests. Degraded forests were reported to be more susceptible to fire than intact forests. In 1997-2005, after the One Million Rice Project, degraded forests were a main cause of fire [22].

Our results, and all recent results, suggest that shrubland is the most important land cover type for focusing on fire prevention. Mechanisms to financially and technically support the restoration of shrubland into peat swamp forests or the conversion of shrubland to other land cover types without causing largescale fires are required.

\subsection{Land Cover and Fire under Different Land Management}

Shrubland was prone to burning regardless of the type of land management or concession. In contrast, in peat swamp forests, fire occurrence was influenced by the type of land management and concession (Table 4). The percentage of burned forest was three times larger in those under cultivation right (33.1\%) than those under industrial forest plantations (8.9\%). Conservation and regular 
production forests rarely faced fires, with only $1.3 \%$ and $3.2 \%$ burned, respectively.

Land management types affected fire occurrence in peat swamp forests. Conservation and regular production forests were less fire-prone than those under other land management types (Table 4), as the previous study found in Kalimantan [30]. This was not due to differences in forest patch sizes because there were no differences in forest patches between different land management types $(\mathrm{p}=0.22$, ANOVA after log-transforming the area to meet normality of errors). This result is probably due to differences in law enforcement because the government prioritizes law enforcement in conservation and protected forests than other types of land management [53].

Concession types also affected fire occurrence in forests. Forests under cultivation rights were three times more prone to fire than forests under industrial forest plantations. This difference may be due to the activities allowed under each concession type. Industrial forest plantations have a zero-burning policy [54]. Wood is a raw material for paper production, and the company will harvest wood from peat swamp forests and convert the forest to an acacia plantation. In contrast, in cultivation right areas, palm oil companies are not interested in wood harvesting, because obtaining permission for logging involves complex and costly procedures [55]. Hence, forest burning is a simple and cheaper option for land clearing. Another difference between concession types may be the spatial arrangement of land cover types. Industrial forest plantations allocate peat swamp forests on one large landscape surrounded by acacia plantations [56]. Consequently, access to these forests by smallholders may be prohibited. Conversely, forests

Table 4. Fire occurrence in peat swamp forests under different concession and land management.

\begin{tabular}{ccccc}
\hline & $\begin{array}{c}\text { (A) Non-burned } \\
\text { area (ha) }\end{array}$ & $\begin{array}{c}\text { (B) Burned } \\
\text { area (ha) }\end{array}$ & $\begin{array}{c}\text { Proportion of B } \\
\text { to the total burned } \\
\text { area (\%) }\end{array}$ & $\begin{array}{c}\text { (B/(A + B) }) \\
\text { Percentage } \\
\text { of burned area (\%) }\end{array}$ \\
\hline $\begin{array}{c}\text { Concession types } \\
\text { Cultivation right }\end{array}$ & 27,539 & 13,655 & 11.5 & 33.1 \\
Release of forest area & 26,656 & 8409 & 7.1 & 24.0 \\
Industrial forest plantation & 367,116 & 35,933 & 30.2 & 8.9 \\
Outside concession & 755,723 & 60,926 & 51.2 & 7.5 \\
Land management types & & & & 30.3 \\
Non-forestland & 43,426 & 18,839 & 16.2 & 23.6 \\
Convertible production & 113,606 & 35,163 & 30.3 & 20.6 \\
forest & 156,663 & 40,585 & 34.9 & 10.5 \\
Limited production forest & 2158 & 253 & 0.2 & 3.2 \\
Protection forest & 642,364 & 21,291 & 18.3 & 1.3 \\
Regular production forest & 218,818 & 2791 & 2.4 & \\
Conservation forest & & & & \\
\hline
\end{tabular}


under cultivation rights are more easily accessible by smallholders because the forest is adjacent to their cultivation area. These results suggest that governmental policies through law enforcement, spatial arrangement of land cover types, and various management schemes for land under different concession types are important factors related to peatland fires.

\subsection{Landholders and Fires}

Even in areas with same commodities, the occurrence of burned areas differed among the types of landholders. Coconut plantations by companies were four times more prone to fire (8.4\%) than coconut cultivation by smallholders $(1.8 \%$; Table 5). Similarly, sago palm plantations by companies were four times more prone to fire $(41.3 \%)$ than sago palm cultivation by smallholders $(10.7 \%$; Table 6). Oil palm plantations by unregistered companies were more prone to fire (8.5\%) than those by registered companies $(3.3 \%)$ or smallholders $(2.1 \%$; Table 7). Acacia plantations under cooperation between companies and smallholders were three times more prone to fire $(21.8 \%$; Table 8$)$ than acacia plantations

Table 5. Fire occurrence in coconut plantations by landholder type.

\begin{tabular}{ccccc}
\hline Landholder types & $\begin{array}{c}\text { (A) Non-burned } \\
\text { area (ha) }\end{array}$ & $\begin{array}{c}\text { (B) Burned } \\
\text { area (ha) }\end{array}$ & $\begin{array}{c}\text { Proportion of B to the } \\
\text { total burned area }(\%)\end{array}$ & $\begin{array}{c}(\mathrm{B} /(\mathrm{A}+\mathrm{B})) \text { Percentage } \\
\text { of burned area }(\%)\end{array}$ \\
\hline Company & 151,433 & $13,847.1$ & 64.5 & 8.4 \\
Smallholder & 408,981 & 7616 & 35.5 & 1.8 \\
\hline
\end{tabular}

Table 6. Fire occurrence in sago palm plantations by landholder type.

\begin{tabular}{ccccc}
\hline Landholder types & $\begin{array}{c}\text { (A) Non-burned } \\
\text { area (ha) }\end{array}$ & $\begin{array}{c}\text { (B) Burned } \\
\text { area (ha) }\end{array}$ & $\begin{array}{c}\text { Proportion of B to the } \\
\text { total burned area (\%) }\end{array}$ & $\begin{array}{c}(\mathrm{B} /(\mathrm{A}+\mathrm{B})) \text { Percentage } \\
\text { of burned area }(\%)\end{array}$ \\
\hline Company & 12,569 & $8,858.0$ & 60.1 & 41.3 \\
Smallholder & 49,084 & 5877 & 39.9 & 10.7 \\
\hline
\end{tabular}

Table 7. Fire occurrence in oil palm plantations by landholder type.

\begin{tabular}{|c|c|c|c|c|}
\hline Landholder types & $\begin{array}{l}\text { (A) Non-burned } \\
\text { area (ha) }\end{array}$ & $\begin{array}{l}\text { (B) Burned } \\
\text { area (ha) }\end{array}$ & $\begin{array}{l}\text { Proportion of B to the } \\
\text { total burned area (\%) }\end{array}$ & $\begin{array}{c}(\mathrm{B} /(\mathrm{A}+\mathrm{B})) \text { Percentage } \\
\text { of burned area }(\%)\end{array}$ \\
\hline Unregistered Company & 155,592 & 14,396 & 57.6 & 8.5 \\
\hline Registered Company & 315,107 & 10,605 & 42.4 & 3.3 \\
\hline Smallholder & 215,581 & 4553 & 31.6 & 2.1 \\
\hline
\end{tabular}

Table 8. Fire occurrence in acacia plantations by landholder type.

\begin{tabular}{ccccc}
\hline $\begin{array}{c}\text { Landholder types } \\
\text { (A) Non-burned (B) Burned Proportion of B to the } \\
\text { area (ha) }\end{array}$ & $\begin{array}{c}(\mathrm{B} /(\mathrm{A}+\mathrm{B})) \text { Percentage } \\
\text { area (ha) }\end{array}$ & $\begin{array}{c}\text { total burned area }(\%) \\
\text { of burned area }(\%)\end{array}$ \\
\hline $\begin{array}{c}\text { Cooperation company } \\
\text { and smallholder }\end{array}$ & 7620 & 1660 & 4.2 & 21.8 \\
Company & 537,120 & 37,973 & 95.8 & 6.6 \\
\hline
\end{tabular}


controlled by a company (6.6\%).

Although previous studies focused on land cover types and neglected or only partly focused on landholders ([21] [23]), our results clearly demonstrated that, even with same commodities, fire occurrence differs depending on landholders (Tables 5-8). In the case of acacia plantations, plantations operated by cooperation between a company and smallholders were three times more prone to fire than those solely operated by the company (Table 8 ). Management by cooperation may be less intensive than management by company. In the cooperation area, land clearing and planting activities were carried out by the company, but after one year, acacia grows without treatment [45]. The company will only return when they harvest the acacia, therefore, the water table in the cooperation area might not be maintained well and fire risk increases.

In the case of oil palm plantations, plantations operated by unregistered company were more susceptible to fire compare to those by registered company or smallholder (Table 7). The Indonesian government has a zero-burning policy; however, this policy is only effective on registered palm oil companies. It is difficult to implement the policy on unregistered palm oil companies. Oil palm plantations operated by companies who are not members of the Roundtable on Sustainable Palm Oil (RSPO) were more fire-prone than RSPO companies in Sumatra and Kalimantan [57]. Unregistered oil palm companies use fire to reduce the cost of land clearing [50]. Under El Niño conditions, fire originally intended for land preparation will become difficult to control and spread into the plantation [58]. Smallholders do not follow the zero-burning policy, but they usually manage their oil palm cultivation intensively [31].

Coconut and Sago cultivations by smallholders were less susceptible to fire than company plantations, as we predicted (Table 5 and Table 6). Coconut cultivation by smallholders in Riau uses a shallow canal to dry peatland and uses tides to maintain soil moisture and provide nutrients to coconut palms [59]. In contrast, industrial coconut plantations operated by a company use a deep canal to develop the plantation and do not use tides to maintain soil moisture. As a result, peatland may become drier, especially in a dry year. Similarly, sago cultivation by smallholders maintains wet conditions [60]. Rubber cultivation is planted by smallholders, and it was one of least-fire-prone land cover types (Table 2). Before the government developed industrial plantations in Riau, the local community developed coconut, sago palms, and rubber cultivation systems in peatland. These traditional cultivation systems could reduce peatland fires as well as providing economic benefits to the local community.

The extent of law enforcement and management schemes, especially the method of landholders use to preserve soil water content, appear to be the factors that affect fire occurrences, even when the same commodities are grown. We could not identify landholders in shrubland using remote sensing images and concession maps. Landholder mapping by a combination of remote sensing and ground surveying is necessary to effectively enforce zero-burning policies on landholders such as encroaching migrants and locals, unregistered companies, 
and acacia cooperation. Furthermore, comparative sociological, economic, and ecological studies of management schemes by different landholders cultivating the same commodity are required for creating sustainable and fire-resistant production systems.

\subsection{Proximity to Roads and Canals and Fires}

In shrubland, the percentage of burned areas gradually increased from $1 \mathrm{~km}$ to $10 \mathrm{~km}$ from the road (Figure 6), while it gradually decreased in the forest. Shrublands were prone to fire up to $4 \mathrm{~km}$ from the canal (Figure 7). Forest areas closer to the canal were more prone to fire.

Road affected fire occurrence, but the pattern differed between peat swamp forests and shrubland (Figure 6). Forests near to roads were susceptible to fire. Road development makes forests more easily accessible by the community and migrants, and local communities claim land ownership by clearing forest with fire. Commonly, forest clearing was conducted adjacent to the roads because this makes transportation of agricultural products easier [61]. For shrubland, fires were used to exhibit land ownership, and as a result, fire occurrences were high for all distances from the road up to $10 \mathrm{~km}$.

Canals can drain water and lower the water table within a distance of up to several kilometres, and thus vegetation becomes more susceptible to fire [62]. Even peat swamp forests became more susceptible to fire (Figure 7), which could be because drainage reduces forest soil moisture. Based on these findings, landscape planning considering proximity to roads and canals is needed.

\section{Conclusion}

Besides predisposing factors, such as climate and hydrology, peatland fires are affected by interactions between land cover types, land management systems,

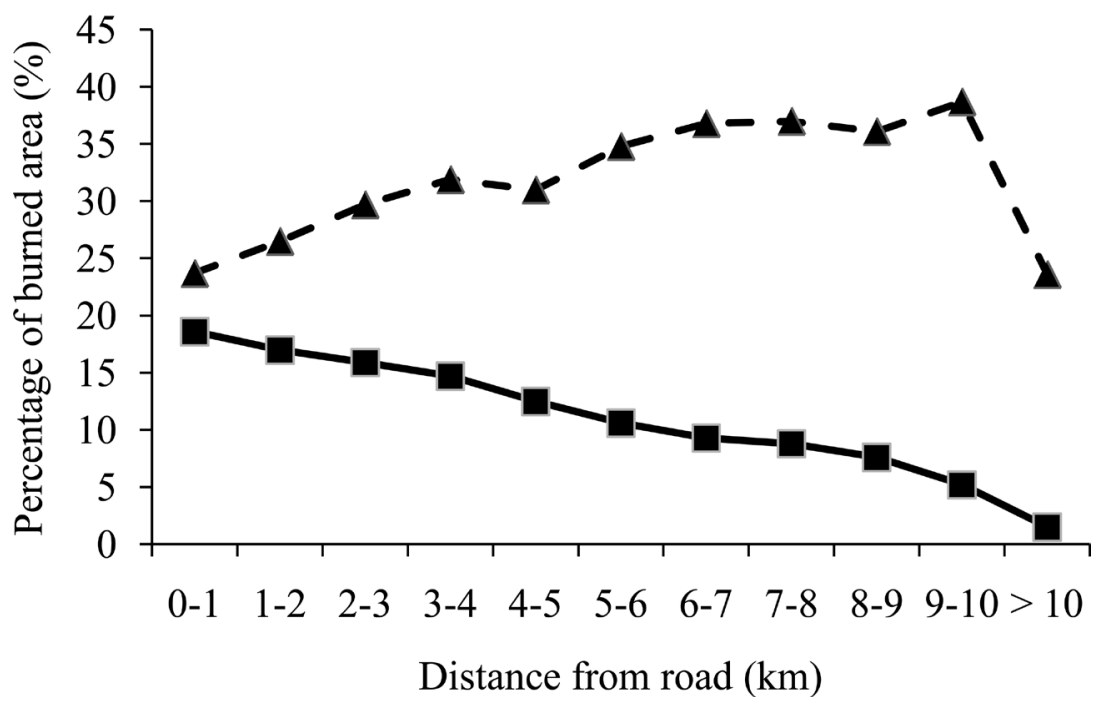

Figure 6. Burned area in relation to distance from roads in shrubland (triangle with dotted line) and in peat swamp forests (square with solid line). 


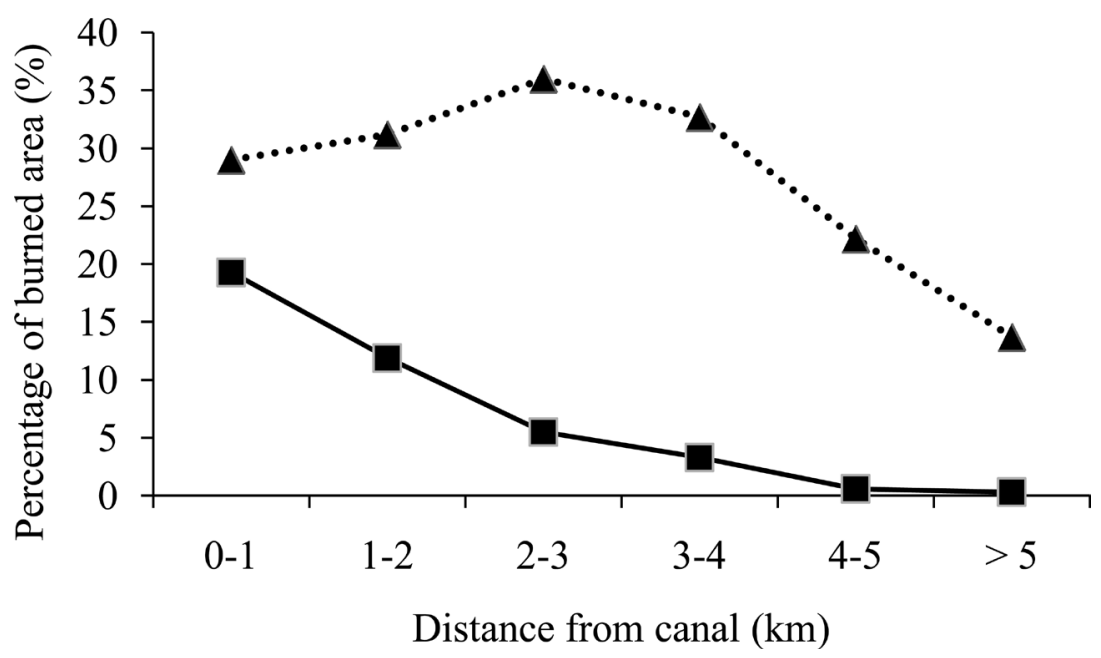

Figure 7. Burned area in relation to distance from canals in shrubland (triangle with dotted line) and in peat swamp forests (square with solid line).

landholders, and proximity to roads and canals. Land cover type was the main factor that affected fire occurrence. In addition, land management systems, landholders, and proximity to roads and canals also affected fire occurrence. To fully understand the direct and indirect causes of peatland fires and develop integrated peatland management practices, further sociological, economical, and ecological studies on law and land management systems, management schemes by different landholders, and spatial arrangements of land cover, roads, and canals are needed.

\section{Acknowledgements}

The authors thank the Riau Provincial Government, Indonesia for permission of conducting the study, and the staff of the Riau Provincial Government for helping the field survey and providing concession map. This work was supported by grants from the Japanese Government (Monbukagakusho/MEXT) scholarship. This research contributes to the Global Land Project (https://glp.earth/).

\section{References}

[1] Page, S.E., Rieley, J.O. and Wüst, R. (2006) Chapter 7 Lowland Tropical Peatlands of Southeast Asia. In: Martini, I.P., Cortizas, A.M. and Chesworth, W., Eds., Peatlands. Evolution and Records of Environmental and Climate Changes, Elsevier Ltd., Amsterdam, 145-172.

[2] Page, S.E. and Hooijer, A. (2016) In the Line of Fire: The Peatlands of Southeast Asia. Philosophical Transactions of the Royal Society Biological Sciences, 371, 1-9. https://doi.org/10.1098/rstb.2015.0176

[3] Miettinen, J., Shi, C. and Liew, S.C. (2016) Land Cover Distribution in the Peatlands of Peninsular Malaysia, Sumatra and Borneo in 2015 with Changes since 1990. Global Ecology and Conservation, 6, 67-78.

[4] Meer, P.J., Van Der and Verwer, C.C. (2011) Towards a Reference Carbon Value for Peat Swamp Forest in Southeast Asia Based on Historical Inventory Data. Workshop on Tropical Wetland Ecosystems of Indonesia: Science Needs to Address Cli- 
mate Change Adaptation and Mitigation, Bali, 1-4.

http://www.forestday.org/fileadmin/tropical-workshop/Plenary-4/31A_VanderMee $\underline{\text { r_Towards reference value.pdf }}$

[5] Page, S., Hoscilo, A., Langner, A., Tansey, K., et al. (2009) Tropical Peatland Fires in Southeast Asia. In: Cochrane, M.A., Ed., Tropical Fire Ecology, Springer, Berlin, 263-287. https://doi.org/10.1007/978-3-540-77381-8_9

[6] The World Bank (2015) Reforming Amid Uncertainty, Indonesia Economic Quarterl. The World Bank, Jakarta.

[7] Mabuhay, J.A., Isagi, Y. and Nakagoshi, N. (2004) Microbial Biomass, Abundance and Community Diversity Determined by Terminal Restriction Fragment Length Polymorphism Analysis in Soil at Varying Periods after Occurrence of Forest Fire. Microbes and Environment, 19, 154-162. https://doi.org/10.1264/jsme2.19.154

[8] Aiken, S.R. (2004) Runaway Fires, Smoke-Haze Pollution, and Unnatural Disasters in Indonesia. American Geographical Society, 94, 55-79. https://doi.org/10.1111/j.1931-0846.2004.tb00158.x

[9] Putra, E.I., Hayasaka, H., Takahashi, H. and Usup, A. (2008) Recent Peat Fire Activity in the Mega Rice Project Area, Central Kalimantan, Indonesia. Journal of Disaster Research, 3, 1-6. https://doi.org/10.20965/jdr.2008.p0334

[10] Wösten, J.H.M., Van Den Berg, J., Van Eijk, P., Gevers, G.J.M., et al. (2006) Interrelationships between Hydrology and Ecology in Fire Degraded Tropical Peat Swamp Forests. Water Resources Development, 22, 157-174. https://doi.org/10.1080/07900620500405973

[11] Chokkalingam, U., Kurniawan, I. and Ruchiat, Y. (2005) Fire, Livelihoods, and Environmental Change in the Middle Mahakam Peatlands, East Kalimantan. Ecology and Society, 10, 1-17. https://doi.org/10.5751/ES-01320-100126

[12] Chokkalingam, U., Suyanto, Permana, R.P., Kurniawan, I., et al. (2007) Community Fire Use, Resource Change, and Livelihood Impacts: The Downward Spiral in the Wetlands of Southern Sumatra. Mitigation and Adaptation Strategies for Global Change, 12, 75-100. https://doi.org/10.1007/s11027-006-9038-5

[13] Goldammer, J.G. (1999) Forests on Fire. Science, 284, 1782-1783. https://doi.org/10.1126/science.284.5421.1782a

[14] Field, R.D., van der Werf, G.R. and Shen, S.S.P. (2009) Human Amplification of Drought-Induced Biomass Burning in Indonesia since 1960. Nature Geoscience, 2, 185-188. https://doi.org/10.1038/ngeo443

[15] Miettinen, J., Hooijer, A., Shi, C., Tollenaar, D., et al. (2012) Extent of Industrial Plantations on Southeast Asian Peatlands in 2010 with Analysis of Historical Expansion and Future Projections. Global Change Biology, 4, 908-918. https://doi.org/10.1111/j.1757-1707.2012.01172.x

[16] Suyanto, S., Applegate, G., Permana, R.P., Khususiyah, N. and Kurniawan, I. (2004) The Role of Fire in Changing Land Use and Livelihoods in Riau, Sumatra. Ecology and Society, 9, 1-11. https://doi.org/10.5751/ES-00632-090115

[17] Hooijer, A., Page, S., Jauhiainen, J., Lee, W.A., et al. (2012) Subsidence and Carbon Loss in Drained Tropical Peatlands. Biogeosciences, 9, 1053-1071. https://doi.org/10.5194/bg-9-1053-2012

[18] Marlier, M.E., DeFries, R.S., Kim, P.S., Koplitz, S.N., et al. (2015) Fire Emissions and Regional Air Quality Impacts from Fires in Oil Palm, Timber, and Logging Concessions in Indonesia. Environmental Research Letters, 10, 1-9. https://doi.org/10.1088/1748-9326/10/8/085005 
[19] Mabuhay, J.A., Nakagoshi, N. and Horikoshi, T. (2003) Microbial Biomass and Abundance after Forest Fire in Pine Forests in Japan. Ecological Research, 18, 431-441. https://doi.org/10.1046/j.1440-1703.2003.00567.x

[20] Miettinen, J., Hooijer, A., Wang, J., Shi, C. and Liew, S.C. (2012) Peatland Degradation and Conversion Sequences and Interrelations in Sumatra. Regional Environmental Change, 12, 729-737. https://doi.org/10.1007/s10113-012-0290-9

[21] Cattau, M.E., Harrison, M.E., Shinyo, I., Tungau, S., et al. (2016) Sources of Anthropogenic Fire Ignitions on the Peat-Swamp Landscape in Kalimantan, Indonesia. Global Environmental Change, 39, 205-219.

[22] Hoscilo, A., Page, S.E., Tansey, K.J. and Rieley, J.O. (2011) Effect of Repeated Fires on Land-Cover Change on Peatland in Southern Central Kalimantan, Indonesia, from 1973 to 2005. International Journal of Wildland Fire, 20, 578-588. https://doi.org/10.1071/WF10029

[23] Gaveau, D.L., Salim, M., Hergoualc'h, K., Locatelli, B., et al. (2014) Major Atmospheric Emissions from Peat Fires in Southeast Asia during Non-Drought Years: Evidence from the 2013 Sumatran Fires. Scientific Reports, 4, 1-7.

[24] Haryati, E. and Nakagoshi, N. (2013) Post-Fire Succession at Forest Vegetation in Giam Siak Kecil Wildlife Reserve, Riau, Indonesia. Hikobia, 16, 335-349.

[25] Stolle, F., Chomitz, K.M., Lambin, E.F. and Tomich, T.P. (2003) Land Use and Vegetation Fires in Jambi Province, Sumatra, Indonesia. Forest Ecology and Management, 179, 277-292.

[26] Page, S.E., Rieley, J., Hoscilo, A., Spessa, A. and Weber, U. (2013) Current Fire Fegimes, Impacts and the Likely Changes IV : Tropical Southeast Asia. In: Goldammer, J.G., Ed., Vegetation Fires and Global Change-Challenges for Concerted International Action a White Paper Directed to the United Nations and International Organizations, Kessel Publishing House, Remagen-Oberwinterl, 89-99.

[27] Gouyon, A. (1999) The Sustainable Development of Tree Crops and the Prevention of Vegetation Fires in South Sumatra, Indonesia: Jungle Rubber. Forest Fire Prevention and Control Project, Palembang.

[28] Galudra, G., van Noordwijk, M., Agung, P., Suyanto, S. and Pradhan, U. (2014) Migrants, Land Markets and Carbon Emissions in Jambi, Indonesia: Land Tenure Change and the Prospect of Emission Reduction. Mitigation and Adaptation Strategies for Global Change, 19, 715-731.

[29] Gaveau, D.L.A., Pirard, R., Salim, M.A., Tonoto, P., et al. (2017) Overlapping Land Claims Limit the Use of Satellites to Monitor No-Deforestation Commitments and No-Burning Compliance. Conservation Letters, 10, 257-264.

https://doi.org/10.1111/conl.12256

[30] Langner, A. and Sieger, F. (2009) Spatiotemporal Fire Occurrence in Borneo over a Period of 10 Years. Global Change Biology, 15, 48-62. https://doi.org/10.1111/j.1365-2486.2008.01828.x

[31] Stolle, F. and Lambin, E.F. (2003) Interprovincial and Interannual Differences in the Causes of Land-Use Fires in Sumatra, Indonesia. Environmental Conservation, 30, 375-387. https://doi.org/10.1017/S0376892903000390

[32] WWF Indonesia (2013) Palming off a National Park. Tracking Illegal Oil Palm Fruit in Riau, Sumatra, WWF Indonesia, Jakarta.

[33] Ekadinata, A., Noordwijk, M., Budidarsono, S. and Dewi, S. (2013) Hot Spots in Riau, Haze in Singapore: The June 2013 Event Analyzed. Policy Brief. Alternatives Slash and Burn Partnership for the Tropical Forest Margins, Nairobi. 
[34] Raharjo, B. and Nakagoshi, N. (2014), Stochastic Approach on Forest Fire Spatial Distribution from Forest Accessibility in Forest Management Units, South Kalimantan Province, Indonesia. Journal of Environmental Protection, 5, 517-529. https://doi.org/10.4236/jep.2014.56055

[35] The World Bank (2014) Hard Choices. The World Bank, Jakarta.

[36] Statistics of Riau Province, Riau in Figure 2015, Statistics of Riau Province, Pekanbaru. http://riau.bps.go.id/websiteV2/pdf_publikasi/Riau-Dalam-Angka-2015.pdf

[37] Roy, D.P., Wulder, M.A., Loveland, T.R., et al. (2014) Landsat-8: Science and Product Vision for Terrestrial Global Change Research. Remote Sensing of Environment, 145, 154-172.

[38] Margono, B.A., Turubanova, S., Zhuravleva, I., Potapov, P., et al. (2012) Mapping and Monitoring Deforestation and Forest Degradation in Sumatra (Indonesia) using Landsat Time Series Data Sets from 1990 to 2010. Environmental Research Letters, 7, 1-16. https://doi.org/10.1088/1748-9326/7/3/034010

[39] Jia, K., Wei, X., Gu, X., Yao, Y., et al. (2014) Land Cover Classification using Landsat 8 Operational Land Imager Data in Beijing, China. Geocarto International, 29, 941-951. https://doi.org/10.1080/10106049.2014.894586

[40] Chavez, P.S. (1996) Image-Based Atmospheric Corrections-Revisited and Improved. Photogrammetric Engineering and Remote Sensing, 62, 1025-1035.

[41] Yacouba, D., Guangdao, H. and Xingping, W. (2009) Applications of Remote Sensing in Land Use/Land Cover Change Detection in Puer and Simao Counties, Yunnan Province. Journal of American Science, 5, 157-166.

[42] Buja, K. and Menza, C. (2013) Sampling Design Tool for ArcGIS Instruction Manual (Silver Spring: National Centers for Coastal Ocean Science).

http://aquaticcommons.org/14676/1/Buja and Menza 2013.pdf

[43] Powell, R.L., Matzke, N., De Souza, C., Clark, M., et al. (2004) Sources of Error in Accuracy Assessment of Thematic Land-Cover Maps in the Brazilian Amazon. Remote Sensing of Environment, 90, 221-234.

[44] Giglio, L., Descloitres, J., Justice, C.O. and Kaufman, Y.J. (2003) An Enhanced Contextual Fire Detection Algorithm for MODIS. Remote Sensing of Environment, 87, 273-282.

[45] Indonesian Working Group on Forest Finance (2010) Estimation of Source of Raw Material Pulp \& Paper Industry. Indonesian Working Group on Forest Finance, Jakarta. (In Indonesian)

http://docslide.us/documents/iwgffstudi-advokasi-pt-rapp-pt-ikpp-di-propinsi-riau -55993ea81e3c6.html

[46] Jensen, J.R. (2005) Introductory Digital Image Processing: A Remote Sensing Perspective. Prentice-Hall, New Jersey.

[47] Miettinen, J., Shi, C. and Chin, S. (2011) Influence of Peatland and Land Cover Distribution on Fire Regimes in Insular Southeast Asia. Regional Environmental Change, 11, 191-201. https://doi.org/10.1007/s10113-010-0131-7

[48] Miettinen, J., Wang, J., Hooijer, A. and Liew, S. (2013) Peatland Conversion and Degradation Processes in Insular Southeast Asia: A Case Study in Jambi, Indonesia. Land Degradation and Development, 24, 334-341. https://doi.org/10.1002/ldr.1130

[49] Clough, Y., Krishna, V.V., Corre, M.D., Darras, K., et al. (2016) Land-Use Choices Follow Profitability at the Expense of Ecological Functions in Indonesian Smallholder Landscapes. Nature Communications, 7, 1-12.

https://doi.org/10.1038/ncomms13137 
[50] Purnomo, H., Shantiko, B., Sitorus, S., Gunawan, H., et al. (2017) Fire Economy and Actor Network of Forest and Land Fires in Indonesia. Forest Policy and Economics, 78, 21-31.

[51] Cochrane, M.A. (2003) Fire Science for Rainforests. Nature, 421, 913-919. https://doi.org/10.1038/nature01437

[52] Langner, A., Miettinen, J. and Siegert, F. (2007) Land Cover Change 2002-2005 in Borneo and the Role of Fire Derived from MODIS Imagery. Global Change Biology, 13, 2329-2340. https://doi.org/10.1111/j.1365-2486.2007.01442.x

[53] Gaveau, D.L.A., Linkie, M., Suyadi, Levang, P. and Leader-Williams, N. (2009) Three Decades of Deforestation in Southwest Sumatra: Effects of Coffee Prices, Law Enforcement and Rural Poverty. Biological Conservation, 142, 597-605.

[54] Pasaribu, S.M. and Supena, F. (2008) Understanding Cause of Forest and Land Fire and the Prevention: Case Study West Kalimantan Province. Socio-Economic of Agriculture and Agribusiness, 8, 1-23.

[55] Ekawati, S. (2013) Evaluation of the Implementation of Decentralization Policy on Production Forest Management. Journal of Forestry Policy Analysis, 10, 187-202. (In Indonesian)

[56] Gunawan, H., Kobayashi, S., Mizuno, K. and Kono, Y. (2012) Peat Swamp Forest Types and Their Regeneration in Giam Siak Kecil-Bukit Batu Biosphere Reserve, Riau, East Sumatra, Indonesia. Mires and Peat, 10, 1-17.

[57] Cattau, M.E., Marlier, M.E. and DeFries, R. (2016) Effectiveness of Roundtable on Sustainable Palm Oil (RSPO) for Reducing Fires on Oil Palm Concessions in Indonesia from 2012 to 2015. Environmental Research Letters, 11, 1-11. https://doi.org/10.1088/1748-9326/11/10/105007

[58] Murdiyarso, D. and Adiningsih, E.S. (2007) Climate Anomalies, Indonesian Vegetation Fires and Terrestrial Carbon Emissions. Mitigation and Adaptation Strategies for Global Change, 12, 101-112. https://doi.org/10.1007/s11027-006-9047-4

[59] Notohadiprawiro, T. (1997) Twenty Five Years Experience in Peatland Development for Agriculture in Indonesia. Biodiversity and Sustainability of Tropical Peatlands, 1997, 301-309.

[60] Indonesia Climate Change Center (2014) Sustainable Peatland Management (SPM) across Sectors Project Report, Indonesia Climate Change Center, Jakarta.

[61] Akbar, A. (2008) Community Based Fire Management as an Effort to Solve the REDD Risk. Tekno Forest Plantation, 1, 11-22. (In Indonesian)

[62] Wösten, J.H.M., Clymans, E., Page, S.E., Rieley, J.O. and Limin, S.H. (2008) Peat-Water Interrelationships in a Tropical Peatland Ecosystem in Southeast Asia. Catena, 73, 212-224. 